\title{
Characterization of Lactic Bacteria Isolated from Raw Milk and Their Antibacterial Activity against Bacteria as the Cause of Clinical Bovine Mastitis
}

\author{
Nada K. Alharbi $(\mathbb{D}$ and Albandary Nasser Alsaloom \\ Biology Department, College of Science, Princess Nourah Bint Abdulrahman University, Riyadh 11671, Saudi Arabia \\ Correspondence should be addressed to Nada K. Alharbi; n.alharbi21@yahoo.com
}

Received 18 October 2021; Revised 1 December 2021; Accepted 3 December 2021; Published 29 December 2021

Academic Editor: Antimo Di Maro

Copyright (c) 2021 Nada K. Alharbi and Albandary Nasser Alsaloom. This is an open access article distributed under the Creative Commons Attribution License, which permits unrestricted use, distribution, and reproduction in any medium, provided the original work is properly cited.

\begin{abstract}
The objectives of this study were the selection of lactic acid bacteria (LAB) isolated from raw milk and studying their technological properties and antibacterial activities against bacteria as the cause of cattle mastitis. Biochemical and molecular identification using 16S-23S rRNA gene spacer analysis and 16S rRNA gene sequencing highlighted the presence of three species: Lactiplantibacillus plantarum, Lactococcus lactis, and Levilactobacillus brevis. The enzymatic characterization followed by the determination of technofunctional properties showed that LAB strains did not exhibit any hemolytic effect and were able to produce protease and lipase enzymes. Isolates showed very high antagonistic activity against Gram-positive and Gram-negative bacteria by producing $\mathrm{H}_{2} \mathrm{O}_{2}$, bacteriocin(s), and organic acid(s). APIZYM micromethod demonstrated that all selected strains are capable of producing valine arylamidase, cystine arylamidase, $\mathrm{N}$-acetyl- $\beta$-glucosaminidase, and $\alpha$-mannosidase. The antibiotic susceptibility assay showed that all selected strains were sensible to the majority of tested antibiotics. Based on these results, it can be concluded that the technological properties of the selected LAB allow considering their industrial use in order to formulate bioactive functional foods or drug(s).
\end{abstract}

\section{Introduction}

Since ancient times, the discovery of antimicrobial drugs has made remarkable progress which plays an important role in the treatment of various types of microbial infections and the reduction of fatalities associated with infections caused by microbes. However, despite this progress, multidrug-resistant pathogenic microorganisms have emerged due to misuse or overuse of commercially available antimicrobial drugs in humans $[1,2]$. Thus, the emergence of previously uncommon infections is considered as a serious medical problem by the Word Health Organization, governments, the public health and scientific communities, as well as health care providers at large. For example, bovine mastitis is one of the most prevalent production diseases affecting the dairy industry worldwide [3]. It can be caused by several associated factors with the host, the environment, the season, the farm management, and the specific agent pathogens, in particular, Staphylococcus and Escherichia coli [4-6]. This situation, associated with adverse side-effects of certain antibiotics, encouraged scientists to search for new antimicrobial agents from plants or bacteria [7].

Lactic acid bacteria (LAB) classified as "generally recognized as safe" (GRAS) microorganisms are one of the most important groups of bacteria in the food industry [8]. They can prevent the development of pathogenic bacteria [9-11] and are able to produce antimicrobial compounds such as lactic acid, acetic acid, diacetyl, acetoin, hydrogen peroxide, and bacteriocins $[10,12-16]$. Therefore, they are suitable for technological and industrial processes. They are used as transformation agents for the fermentation of milk and other food products and have several technological roles, and participate in the formation of flavors and rheological qualities of cheeses and fermented milk $[8,17]$. In addition, 
LAB strains belonging to the genera Lactobacillus and Enterococcus (L. acidophilus, L. fermentum, L. casei, L. reuteri, L. rhamnosus, L. helveticus, L. lactis, L. crispatus, L. gasseri, L. plantarum, E. faecalis, and E. faecium) may be used as probiotics because they possess specific beneficial health effects on both humans and animals [11, 18-21].

The primary food sources of LAB probiotics are raw milk and artisanal dairy products [14]. Raw cow milk is consumed in different regions of the world and has been subjected to various studies [20-24]. To our knowledge, there are no available studies that focuses on the characterization of LAB isolated from Saudi raw cow milk.

Within this framework which is integrated into the current study, the principal aim is the selection of LAB strains with antimicrobial activity against bacteria responsible for mastic and technological properties, isolated from Saudi raw cow milk. Indeed, the first part was devoted to the morphological and molecular identification of isolated LAB strains. Then, the enzymatic characterizations followed by the determination of the technological properties of each isolate were realized.

\section{Materials and Methods}

2.1. Isolation, Phenotypic, and Biochemical Characterization of $L A B$ Strains. In the present study, forty samples of raw milk were aseptically collected and used to isolate the mesophilic LAB strains. These samples have been provided from Al Ihsa farm, Charguia (Saudi Arabia). Man, Rogosa, and Sharpe (MRS) agar (Pronadisa, Madrid, Spain) was used for isolation of the strains after incubation at $30^{\circ} \mathrm{C}$ during $48 \mathrm{~h}$. Strains were purified several times and stored at $-20^{\circ} \mathrm{C}$ in MRS broth containing 20\% glycerol.

The standard microbiological criteria were used to describe isolated/selected strains (colony shape, cell morphology, motility, and Gram staining) [25]. Catalase and oxidase tests were performed according to the methods described by Guiraud [26]. Only Gram-positive, catalase, and oxidase negative strains were considered for further analyses. Other phenotypic characteristics were determined using API 50CHL and 20E kits (BioMerieux) according to Melinda et al. [27].

2.2. Molecular Identification. The genotypic identification of selected isolates was performed using $16 \mathrm{~S} / 23 \mathrm{~S}$ ribosomal RNA (rRNA) primers (Invitrogen) $16 \mathrm{~S} 5^{\prime} \longrightarrow 3^{\prime}$ GCTGGATCACCTCCTTTC, 23S $5^{\prime} \longrightarrow 3^{\prime}$ AGTGCCAAGGCATCCACC as described by Ben Moussa et al. [19]. DNA extraction was carried out using a modified genomic DNA isolation protocol as described by Aouadhi et al. [28]. The PCR products were analyzed on a $1 \%(\mathrm{w} / \mathrm{v})$ agarose gel.

The preliminary identification of isolated strains was confirmed by sequencing 16S rRNA genes after PCR amplification using the universal primers Fd1 and Rd1 (Fd1, $5^{\prime}$ AGAGTTTGATCCTGGCTCAG- ${ }^{\prime}$ and Rd1, 5'-AAGGA GGTGATCCAGCC-3') (Invitrogen) followed by sequencing as described by Aouadhi et al. [28].

\subsection{Antimicrobial Activity}

2.3.1. Isolation and Phenotypic Identification of Bacteria. Escherichia coli and Staphylococcus aureus were isolated from cows suffering from clinical mastitis as previously described by Klibi et al. [29] and were used to evaluate the antibacterial power of isolated LAB strains. The identification of both strains was carried out using molecular methods after DNA extraction. The species-specific PCR nuc and uidA genes were used for the identification of $S$. aureus and E. coli isolates, respectively $[24,25]$ (data not shown).

2.3.2. Microbial Strains. The LAB strains were individually tested for their antibacterial activities against four indicator microorganisms (Salmonella typhimurium NCTC 6017, Pseudomonas aeruginosa ATCC 27853, Listeria monocytogenes ATCC 7644, and Bacillus subtilis). Bacterial strains were grown in tryptocasein soybean agar (TSA) and incubated at $37^{\circ} \mathrm{C}$ for $24 \mathrm{~h}$.

2.3.3. Agar Well Diffusion Assay. The antagonistic activity of isolated strains was determined by the agar well diffusion assay as described by Boularés et al. [9] and Topisirovic et al. [16]. Twenty milliliters of BHI agar was inoculated with $100 \mu \mathrm{L}$ of each suspension bacteria and poured into a Petri dish. Then, wells of $5 \mathrm{~mm}$ in diameter were perforated, and $15 \mu \mathrm{L}$ of an overnight culture of the LAB strain was loaded into the wells. Subsequently, each antagonistic activity was related to the area (square millimeter) of the clear zone observed surrounding wells after incubation at $37^{\circ} \mathrm{C}$ for $24 \mathrm{~h}$. Strains showing the highest antibacterial activity were then tested for technological properties.

\subsection{Technological Properties of Isolated Strains}

2.4.1. Hemolytic Activities. To determine the hemolytic power, the selected LAB strains were streaked on blood agar and incubated at $37^{\circ} \mathrm{C}$ for 24 hours. The LAB strains that produce green-hued zones around the colonies (alpha-hemolysis) or those that do not produce any effect on the blood agar (gamma-hemolysis) were considered nonhemolytic. Isolates producing zones of blood lyse around the colonies are classified as hemolytic (beta-hemolysis) [30].

2.4.2. Proteolytic Activities. The proteolytic activities of tested strains were performed using skimmed milk and gelatine agar. In fact, the surface-dried medium previously mentioned was streaked with an overnight culture of the strain. After incubation, the proteolysis was determined by measurement of the area (square millimeter) of the clear zone surrounding the inoculated spots $[31,32]$.

2.4.3. Lipolytic Activities. The production of extracellular lipases and extracellular phospholipids (lecithinase) was determined, respectively, on nutritive agar plates that contained $1 \%$ Tween $20,1 \%$ Tween 80 , and Tributyrin as described above [22] and on egg yolk agar [33]. Lipolytic 
activity was shown/detected by the appearance of a precipitated zone around and under each colony in plates containing Tween [34] or an opaque ring surrounding lecithinase positive colonies after incubation for $48 \mathrm{~h}$.

2.4.4. Enzymatic Activity. The characterization of the enzymatic activities of selected strains was realized using the APIZYM galleries according to the manufacturer (BioMérieux). In fact, the inoculation of the cupules of APIZYM strips was performed by a fresh bacterial suspension obtained after suspending colonies of each strain in $2 \mathrm{ml}$ of sterile distilled water. After incubation at $37^{\circ} \mathrm{C}$ for $4 \mathrm{~h}$, the reaction was terminated by the addition of the APIZYM reagents (ZYM A and ZYM B). Enzymatic activity was graded from 1 to 5 according to the color reaction chart. The approximate number of free nanomole hydrolyzed substrate was obtained from the color intensity: 0 : no activity; 1 : liberation of $5 \mathrm{nmol} ; 2: 10 \mathrm{nmol} ; 3: 20 \mathrm{nmol} ; 4: 30 \mathrm{nmol}$; and $5: 40 \mathrm{nmol}[9]$.

2.4.5. Acidification Activity. The acidifying activity of selected strains was measured using titratable acidity (degree Dornic, ${ }^{\circ} \mathrm{D}$ ) [9] and $\mathrm{pH}$ measurement. The strains were subcultured in MRS broth at $37^{\circ} \mathrm{C}$ for $24 \mathrm{~h}$. The fresh microbial culture was inoculated with $1 \%$ inoculum $(1 \mathrm{ml} /$ $100 \mathrm{ml}$ ) into sterile skim milk and incubated at $37^{\circ} \mathrm{C}$. Titratable acidity and $\mathrm{pH}$ were determined after $8,10,24$, and $48 \mathrm{~h}$ of incubation at $37^{\circ} \mathrm{C}$.

2.5. Antibiotic Susceptibility. Susceptibility to antibiotics of selected strains was evaluated using a disc diffusion test according to the break points recommended by the National Committee for Clinical Laboratory Standards [35]. The obtained data were expressed as sensitive ( $\geq 21 \mathrm{~mm}$ zone of inhibition), intermediate ( $16-20 \mathrm{~mm})$, or resistant $(\leq 15 \mathrm{~mm})$ [36]. Six antibiotics such as ampicillin $(10 \mu \mathrm{g})$, chloramphenicol $(30 \mu \mathrm{g})$, colistin $(50 \mu \mathrm{g})$, tetracycline (30 UI), ciprofloxacin $(5 \mu \mathrm{g})$, cefoxitin $(30 \mu \mathrm{g}))$ were used to determine the susceptibility of selected isolates to antibiotics. The multiple antibiotic resistance (MAR) index of the isolates was evaluated by the method described by Ngwai et al. [37].

2.6. Characterization of Antimicrobial Substance. The agar well diffusion technique was used for the characterization of antimicrobial substances synthesized by LAB strains (bacteriocins, organic acids, and hydrogen peroxide) [10]. Overnight cultures of selected strains grown in MRS broth were centrifuged at $6,000 \times \mathrm{g}$ for $10 \mathrm{~min}$, and the supernatants were collected and divided into 4 tubes for different treatments: one was heat treated (boiled) for $10 \mathrm{~min}$, the second was neutralized to $\mathrm{pH} 7$ with $6 \mathrm{~N} \mathrm{NaOH}$, the third was treated with $0.5 \mathrm{mg} / \mathrm{mL}$ catalase, and the fourth was untreated. The supernatants were subsequently filter sterilized $(0.22 \mu \mathrm{m})$, and $100 \mu \mathrm{L}$ of each supernatant was poured into wells made on agar plates and inoculated with $1 \%$ (vol/vol) overnight cultures of indicator pathogens, as previously listed. The diameters $(\mathrm{mm})$ of inhibition zones were measured after they were incubated at $37^{\circ} \mathrm{C}$ for $24 \mathrm{~h}$.

2.7. Statistical Analysis. All the results are expressed as mean \pm standard deviation of three replications. The data were processed using Microsoft Excel 2007 to determine differences between means. Statistical significance for differences was determined at a $5 \%$ probability level.

\section{Results and Discussion}

3.1. Identification of Isolated $L A B$. Throughout the current investigation, one hundred isolates of $\mathrm{LAB}$ were collected from raw cow milk; however, only seven strains were selected for further analysis, based on their important antagonistic activity against bacteria responsible for mastic and four undesirable bacteria. Thus, they were characterized using two complementary approaches in classical microbiology, namely, the morphological and biochemical identification, followed by molecular characterization. The phenotypic identification shows that the morphological and physiological characteristics of LAB are present in all selected strains. They were Gram-positive and catalase and oxidase negative. Next, the results obtained from microscopic observation showed that selected isolates showed two types of cells; five isolates were rod-shaped (ILT1, ILT2, ILT3, ILT5, and ILT6) and two isolates (ILT4 and ILT6) were coccoid. The initial identification of different selected isolates/strains was followed by a biochemical identification which was carried out using API systems (API $50 \mathrm{CH} \mathrm{L}$ and API 20E). Obtained data indicated that except for strain ILT3, all other isolates hydrolyzed D-mannitol, D-sucrose, D-trehalose, D-melezitose, and D-turanose. Likewise, gentiobiose was degraded by all strains except strain ILT4. In addition, $71 \%$ of the selected strains hydrolyzed D-galactose and glucose, and $43 \%$ degraded ribose and D-galactose. Also, amygdalin and L-arabinose were hydrolyzed by $57 \%$ and $29 \%$ of the strains, respectively. On the other hand, only the ILT4 strain is able to degrade D-melibiose and tryptophan, while the ILT3 strain can degrade urea.

The various patterns of catabolic activity were obtained by the API systems, and by using the APIWEB software, we were able to preliminary identify the different isolated strains. In fact, obtained biochemical profiles of selected strains enabled good identification to the level of genera Lactobacillus and Lactococcus with an identity percentage between 97 and 99\% (Table 1).

The molecular identification was based on the polymorphism of the intergenic spaces between the $16 \mathrm{~S}$ and $23 \mathrm{~S}$ genes encoding the rRNAs of the selected strains. Indeed, the variability in the length and the sequence of the $16 \mathrm{~S} / 23 \mathrm{~S}$ intergenic region rRNA or ITS (internal transcribed spacer) is used for identifying the lactic microbiota [38]. Therefore, we analyzed the number of bands obtained after PCR amplification with the $23 \mathrm{~S} / 16 \mathrm{~S}$ primers to identify the different selected strains. Figure 1 highlights the existence of two different types of profile migration. Profile 1 (two bands of 300 and $500 \mathrm{bp}$ ) was found in five strains (ILT1, ILT2, 
TABLE 1: Biochemical and molecular identification and nature of the inhibitory substance produced by selected LAB strains.

\begin{tabular}{lccc}
\hline LAB strains & \multicolumn{2}{c}{$\begin{array}{c}\text { Identification by the API system and molecular characterization } \\
\text { Percentage of identification }\end{array}$} & Significant taxons \\
\hline ILT1 & 98 & Lactiplantibacillus plantarum & Organic acids + hydrogen peroxide \\
ILT2 & 97 & Lactiplantibacillus plantarum & Organic acids \\
ILT3 & 99.9 & Lactiplantibacillus plantarum & Organic acids + hydrogen peroxide \\
ILT4 & 99 & Lactococcus lactis & Organic acids + bacteriocins \\
ILT5 & 98 & Levilactobacillus brevis & Organic acids + hydrogen peroxide \\
ILT6 & 99 & Lactococcus lactis & Organic acids \\
ILT7 & 97 & Levilactobacillus brevis & Organic acids + hydrogen peroxide \\
\hline
\end{tabular}

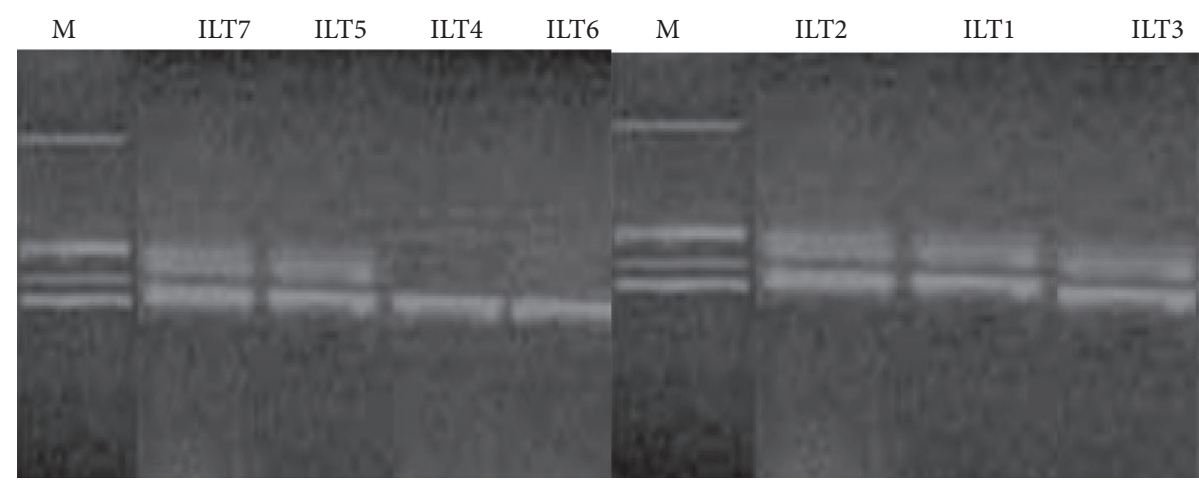

FIgURe 1: Amplification profile by 16S / 23S primers on agarose gel (1.5\%). M: 100 bp marker (Promega, USA).

TABLE 2: Antimicrobial potential of selected LAB strains against six pathogenic bacteria.

\begin{tabular}{|c|c|c|c|c|c|c|}
\hline \multirow[b]{2}{*}{ LAB strains } & \multicolumn{6}{|c|}{ Indicator strains } \\
\hline & Escherichia coli & Bacillus subtilis & Listeria monocytogenes & $\begin{array}{l}\text { Staph. } \\
\text { aureus }\end{array}$ & Salmonella typhimurium & Pseudomonas aeruginosa \\
\hline ILT6 & +++ & +++ & ++++ & +++ & ++ & ++ \\
\hline ILT7 & + & ++ & + & +++ & ++ & +++ \\
\hline ILT1 & +++ & +++ & +++ & ++ & +++ & +++ \\
\hline ILT2 & ++ & +++ & +++ & ++ & ++ & +++ \\
\hline ILT3 & + & ++ & + & + & + & + \\
\hline ILT4 & ++ & +++ & +++ & ++++ & ++++ & +++ \\
\hline ILT5 & +++ & +++ & ++++ & ++ & +++ & ++ \\
\hline
\end{tabular}

Note. -: negative reaction; +: area of inhibition zone $<200 \mathrm{~mm}^{2} ;++$ : area of inhibition zone between 200 and $400 \mathrm{~mm}^{2}$; +++: area of inhibition zone between 400 and $600 \mathrm{~mm}^{2}$; ++++: area of inhibition zone $>600 \mathrm{~mm}^{2}$.

ILT3, ILT5, and ILT7) which confirmed that these isolates are lactobacilli, and profile 2 (a single band of $300 \mathrm{bp}$ ) in two strains (ILT4 and ILT6) which confirmed to belong to the genus Lactococcus. Therefore, molecular identification confirmed the results obtained by biochemical identification.

3.2. Antibacterial Activity. The ability of each selected strain to inhibit the growth of two isolated bacteria from cows suffering from clinical mastitis (E. coli and St. aureus) and four undesirable reference species ( $S$. typhimurium, $P$. aeruginosa, L. monocytogenes, and B. subtillis) is shown in Table 2. In fact, LAB strains showed varied antibacterial power against pathogenic bacteria with an inhibition zone ranging between 6 and $12 \mathrm{~mm}$. In fact, the highest inhibition was observed by the ILT4 strain while the ILT3 strain demonstrated the weakest antimicrobial potential. These results are in agreement with those obtained by other researchers [21, 23, 39] which demonstrated that the LAB strains showed different degrees of antagonistic activity against pathogenic bacteria.

Based on obtained antimicrobial data, it can be concluded that the selected LAB strains showed slightly stronger antimicrobial activity against Gram-positive bacteria (L. monocytogenes, S. aureus, and B. subtillis) than against Gram-negative (E. coli, S. typhimurium, and P.aeruginosa). This finding corroborates previous investigations which reported that Gram-positive bacteria are generally more sensitive to the bactericidal effect of lactic acid bacteria than Gram-negative bacteria $[21,24,40]$. Indeed, the resistance of Gram-negative bacteria to the antimicrobial compounds of LAB can be explained by the fact that their cytoplasmic membrane is protected by the outer membrane which is rich in lipopolysaccharides [41]. It has been noted that the antagonistic activity of LAB could be due to the production of 
inhibitory substances like organic acids, hydrogen peroxide, or bacteriocin [12].

\subsection{Determination of the Nature of the Inhibitory Substance.} The nature of the inhibitory substances produced by the seven strains is studied by the well diffusion antimicrobial method in the presence of indicator bacteria. For all lactic acid strains, no antagonist effect was detected in bacterial supernatants adjusted to $\mathrm{pH} 6.5$, suggesting that the antibacterial activity of these strains is due to the production of organic acid (s). Moreover, the treatment of the supernatants with proteinase $\mathrm{K}(1 \mathrm{mg} / \mathrm{ml})$ and trypsin $(1 \mathrm{mg} / \mathrm{ml})$ inhibited the antagonistic activity of only one strain (ILT4), which suggests that in addition to organic acids, the antibacterial activity of this strain ILT4 is due to the production of bacteriocin (of protein nature). Furthermore, the addition of catalase $(300 \mathrm{U} / \mathrm{ml})$ to the supernatants of 4 strains (ILT1, ILT3, ILT5, and ILT7) decreases the size of the inhibition halos. Thus, these four strains are producers of hydrogen peroxide too.

The results obtained by the characterization of the inhibiting substances of the different strains are summarized in Table 1 and show that the major inhibition agents produced by selected strains are the organic acids produced by the different lactic acid strains. The retention of antimicrobial activity, after the elimination of the effect of lactic acid, confirms the existence of other antibacterial substances such as hydrogen peroxide and bacteriocins. The involvement of hydrogen peroxide in the process of bacterial growth inhibition by lactic acid bacteria has been established. When released in sufficient concentrations, it can induce self-inhibition or inhibit other contaminants in their environment [42]. In addition, some lactic acid bacteria produce bacteriocins with a varied spectrum of inhibition [15], two of which have been particularly characterized: nisin produced by Lc. lactis ssp. lactis has a broad spectrum of inhibition affecting most lactococci and other Gram-positive organisms, and diplococcin produced by Lc. lactis ssp. cremoris [43].

We can conclude that selected LAB with antimicrobial activity produce different inhibition molecules: organic acids, hydrogen peroxide, and bacteriocins.

\subsection{Technological Properties}

3.4.1. Acidifying Activity. One of the industrially important features of lactic acid bacteria is acidifying activity. The results are illustrated in Table 3. It was demonstrated that all selected LAB isolates/strains showed a progressive production of lactic acid (an increase in the acidity of the medium). The latter is accompanied by a lowering of the $\mathrm{pH}$ of the medium. After 6 hours of incubation, the $\mathrm{pH}$ values varied between 6.68 and 6.94, and the acidity of the medium was between 20.5 D (strain ILT6) and 27.3 D (strain ILT3). After 24 hours of incubation, the $\mathrm{pH}$ values decrease and lie between 4.83 and 5.22. As acidity increases, it reaches $103.3^{\circ}$
TABLE 3: Acidifying activity of selected LAB strains.

\begin{tabular}{lcccccc}
\hline \multirow{2}{*}{$\begin{array}{l}\text { LAB } \\
\text { strains }\end{array}$} & \multicolumn{5}{c}{ 6h } & \multicolumn{2}{c}{$8 \mathrm{~h}$} & \multicolumn{2}{c}{$24 \mathrm{~h}$} \\
& $\mathrm{pH}$ & Acidity $\left({ }^{\circ} \mathrm{D}\right)$ & $\mathrm{pH}$ & Acidity $\left({ }^{\circ} \mathrm{D}\right)$ & $\mathrm{pH}$ & Acidity $\left({ }^{\circ} \mathrm{D}\right)$ \\
\hline ILT4 & 6.75 & 25.3 & 6.40 & 33 & 4.83 & 104.3 \\
ILT 7 & 6.70 & 25 & 6.51 & 31 & 5.01 & 86 \\
ILT 1 & 6.62 & 27.3 & 5.98 & 40 & 4.75 & 114 \\
ILT 6 & 6.94 & 20.5 & 6.55 & 26 & 5.08 & 84 \\
ILT5 & 6.87 & 22.6 & 6.53 & 29.6 & 5 & 87 \\
ILT3 & 6.70 & 26.6 & 6.61 & 28 & 4.90 & 90.3 \\
ILT2 & 6.79 & 24.6 & 6.43 & 32.6 & 5.22 & 81.6 \\
\hline
\end{tabular}

$\mathrm{D}$ (10.3 $\mathrm{g}$ of lactic acid/l). Indeed, the most acidifying strain was isolate ILT1 while the least acidifying was ILT2. Our results agree with those of Idoui and Karam [44], who found that Lc. lactis subsp. lactis, Ln. lactis, and Lc. lactis subsp. cremoris produced amounts of lactic acid greater than $8.5 \mathrm{~g} / \mathrm{l}$ after incubation for $24 \mathrm{~h}$. On the other hand, Cheriguene et al. [22] reported that the lower acidifying activity was of Lc. lactis subsp. cremoris, isolated from goat's milk $(6 \mathrm{~g} / \mathrm{l})$ and of Lc. lactis subsp. lactis $(7.5 \mathrm{~g} / \mathrm{l})$ after $24 \mathrm{~h}$.

3.4.2. Lipase Production: Lipolytic Activity. The lipase production test, carried out on agar medium using Tween 20 (lauric acid ester), showed the presence of lipolytic activity in all selected LAB, except strain ILT3. These results are consistent with the work carried out by El Sawah et al. [45] showing the expression of extracellular lipolytic activity in Lactobacillus delbrueckii subsp. bulgaricus.

3.4.3. Protease Production: Proteolytic Activity. The proteolytic activity of selected strains was performed using milk and gelatin agars. The obtained data demonstrated that all strains were able to hydrolyze caseins, but a weak activity was observed for gelatin, which suggests that proteases from $\mathrm{LAB}$ appear to have more affinity for caseins in milk than gelatin. These results are in agreement with those obtained by Idoui and Karam [44], who found that LAB, isolated from traditional cow butter from the region of Jijel, exhibits a proteolytic character. The proteolytic activity of LAB is essential for their growth in milk as well as for the development of the organoleptic properties of different dairy products [19, 37]. In this context, Liu et al. [46] suggested that knowledge of the variations in proteolytic system components could be used to improve the sensory characteristics of dairy and other fermented food products by supporting the strain selection process.

3.4.4. Hemolytic Activity. The tested LAB did not exhibit any hemolytic effect on the blood agar, corroborating the previous findings which showed that the majority of $\mathrm{LAB}$ strains are nonhemolytic [30-47].

3.5. Enzymatic Profile: APIZYM. The enzymatic activities of 7 selected $\mathrm{LAB}$ strains were studied based on the 
TABLE 4: Enzymatic activity detected using the APIZYM system of selected LAB strains.

\begin{tabular}{|c|c|c|c|c|c|c|c|}
\hline \multirow{2}{*}{ Enzymes } & \multicolumn{7}{|c|}{ Strains } \\
\hline & ILT1 & ILT2 & ILT3 & ILT4 & ILT5 & ILT6 & ILT7 \\
\hline Alkaline phosphate & 0 & 0 & 0 & 0 & 0 & 0 & 0 \\
\hline Esterase $\left(\mathrm{C}_{4}\right)$ & 5 & 5 & 5 & 0 & 5 & 5 & 0 \\
\hline Esterase lipase $\left(C_{8}\right)$ & 0 & 5 & 5 & 5 & 5 & 10 & 5 \\
\hline Lipase $\left(\mathrm{C}_{14}\right)$ & 0 & 5 & 5 & 5 & 5 & 5 & 5 \\
\hline $\begin{array}{l}\text { Leucine } \\
\text { arylamidase }\end{array}$ & 0 & 0 & 0 & 0 & 0 & 0 & 0 \\
\hline Valine arylamidase & 5 & $>40$ & 30 & 5 & 10 & $>40$ & 10 \\
\hline $\begin{array}{l}\text { Cystine } \\
\text { arylamidase }\end{array}$ & 5 & $>40$ & 20 & 10 & 5 & $>40$ & 10 \\
\hline Trypsin & 0 & 5 & 0 & 0 & 0 & 0 & 0 \\
\hline a-Chymotrypsin & 0 & 0 & 0 & 0 & 0 & 0 & 0 \\
\hline Acid phosphatase & 0 & 0 & 0 & 0 & 0 & 0 & 0 \\
\hline $\begin{array}{l}\text { Naphthol- } \\
\text { phosphohydrolase }\end{array}$ & 0 & 20 & 0 & 0 & 0 & 0 & 0 \\
\hline$\alpha$-Galactosidase & 5 & 0 & 0 & 5 & 5 & 5 & 0 \\
\hline$\beta$-Galactosidase & 0 & 0 & 0 & 0 & 0 & 0 & 0 \\
\hline B-Glucuronidase & 5 & 30 & 0 & 5 & 0 & 5 & 0 \\
\hline Glucosidase & 0 & 0 & 0 & 0 & 0 & 0 & 0 \\
\hline B-Glucosidase & 0 & 0 & 0 & 5 & 0 & 10 & 0 \\
\hline $\begin{array}{l}\text { N-Acetyl- } \\
\beta \text {-glucosaminidase }\end{array}$ & 10 & 10 & $>40$ & $>40$ & 5 & 30 & 5 \\
\hline a-Mannosidase & 5 & $>40$ & 20 & 20 & 5 & $>20$ & 5 \\
\hline$\alpha$-Fucosidase & 0 & 0 & 0 & 0 & 0 & 0 & 0 \\
\hline
\end{tabular}

Enzymatic activity (approximate values) expressed as free nanomole hydrolyzed substrate was obtained from the color intensity. 0 : no activity; 1 : liberation/released of $5 \mathrm{nmol} ; 2: 10 \mathrm{nmol} ; 3: 20 \mathrm{nmol} ; 4: 30 \mathrm{nmol}$; and 5 : $>40 \mathrm{nmol}$.

semiquantitative APIZYM method. The obtained results showed that the enzyme intensity depends on the strain tested (Table 4). Indeed, all strains were able to produce valine arylamidase, cystine arylamidase, $\mathrm{N}$-acetyl- $\beta$-glucosaminidase, and $\alpha$-mannosidase, but with differences in the production level. The production of other enzymes varied according to the tested strains. The enzymatic profiles of the Lactobacillus and Lactococcus selected strains were, in general, similar to those demonstrated by other research groups [30]. The enzymatic activity is important for many functions of the tested cultures. For example, the production of lipase by Lactobacillus strains can be highlighted by their roles in cheese production, like the acceleration of maturation and enzyme modification. Therefore, these results are valuable for both industrial and research purposes.

3.6. Antibiotic Resistance. The results of the antibiotic resistance analyses of seven selected strains against six different antibiotics, using the disk diffusion method, are summarized in Table 5. All tested strains were resistant to ciprofloxacin, tetracycline, and colistin, as well as sensitive to chloramphenicol. The majority of strains were susceptible to ampicillin and cefoxitin. The obtained data are in agree with other research studies which reported that the majority of $\mathrm{LAB}$ strains isolated from milk and animal rumen are resistant to ciprofloxacin, streptomycin, gentamicin, tetracycline, and vancomycin [39, 48, 49]. In addition, Lukášová
TABle 5: Antibiogram determined by antibiotic discs of selected strains of lactic acid bacteria.

\begin{tabular}{lcccccc}
\hline Antibiotic & ILT1 & ILT2 & ILT3 & ILT4 & ILT5 & ILT6 \\
\hline CIP & R & R & R & R & R & R \\
CL 50 & $\mathrm{R}$ & $\mathrm{R}$ & $\mathrm{R}$ & $\mathrm{R}$ & $\mathrm{R}$ & $\mathrm{R}$ \\
C & $\mathrm{S}$ & $\mathrm{S}$ & $\mathrm{S}$ & $\mathrm{S}$ & $\mathrm{S}$ & $\mathrm{S}$ \\
TE 30 & $\mathrm{R}$ & $\mathrm{R}$ & $\mathrm{R}$ & $\mathrm{R}$ & $\mathrm{R}$ & $\mathrm{R}$ \\
FOX 30 & $\mathrm{~S}$ & $\mathrm{~S}$ & $\mathrm{~S}$ & $\mathrm{~S}$ & $\mathrm{~S}$ & $\mathrm{R}$ \\
AM 10 & $\mathrm{R}$ & $\mathrm{S}$ & $\mathrm{S}$ & $\mathrm{S}$ & $\mathrm{R}$ & $\mathrm{R}$ \\
\hline
\end{tabular}

AM: ampicilline; CL 50: colistine; CIP: ciprofloxacine; TE 30: tetracycline; C: chloramphenicol; FOX: cefoxitin; R: resistant. S: sensible.

and Šustáčková [50] explained that the overuse of antibiotics in the treatment and prophylaxis of bacterial infections could be the main factor in bacterial resistance to these drugs. In addition, other practices on farms can also promote the development of antibiotic resistance in bacteria that infect animals.

In conclusion, $\mathrm{LAB}$ are used in the dairy industry and for fermentation of many other food (milk, plant, dough, cereals, and beverages) products thanks to their various technological properties. In the present study, seven selected LAB strains isolated from Saudi raw milk were further studied to determine their antibacterial compounds and technological properties. The selected strains inhibited pathogenic and spoilage Gram-negative and Gram-positive bacteria by individually, additive or synergistic activity of organic acids, hydrogen peroxide, and bacteriocins, demonstrating that they possess suitable in vitro probiotic properties which can be applied in the formulation of bioactive functional foods or in the formulation of drugs.

\section{Data Availability}

No data were used to support this study.

\section{Conflicts of Interest}

The authors declare that they have no conflicts of interest.

\section{Acknowledgments}

This research was supported by the Princess Nourah Bint Abdulrahman University Researchers supporting Project number (PNURSP2022R153), Princess Nourah Bint Abdulrahman University, Riyadh, Saudi Arabia.

\section{References}

[1] K. Poole, "Efflux-mediated antimicrobial resistance," Journal of Antimicrobial Chemotherapy, vol. 56, no. 1, pp. 20-51, 2005.

[2] D. J. Newman, G. M. Cragg, and K. M. Snader, "The influence of natural products upon drug discovery," Natatural Product Research, vol. 17, pp. 215-234, 2003.

[3] G. A. Contreras and J. M. Rodríguez, "Mastitis: comparative etiology and epidemiology," Journal of Mammary Gland Biology and Neoplasia, vol. 16, no. 4, pp. 339-356, 2011.

[4] S. Ben Hassen, L. Messadi, and B. A. Hassen, "Identification et caractérisation des espèces de Staphylococcus isolées du lait de 
vaches atteintes ou non de mammite," Annales de Médecine Vétérinaire, vol. 147, pp. 41-47, 2003.

[5] S. Taponen and S. Pyorala, "Coagulase-negative staphylococci as cause of bovine mastitis-not so different from Staphylococcus aureus?" Veterinary Microbiology, vol. 134, no. 1-2, pp. 29-36, 2009.

[6] V. Piessens, E. Van Coillie, B. Verbist et al., "Distribution of coagulase-negative Staphylococcus species from milk and environment of dairy cows differs between herds," Journal of Dairy Science, vol. 94, no. 6, pp. 2933-2944, 2011.

[7] A. S. Al-Zubairi, A. B. Abdul, M. M. Elhassan, M. Youssif, S. I. A. Wahab, and S. Moham, "Antibacterial and antioxidant activities of Typhonium flagelliforme (Lodd.) blume tuber," American Journal of Biochemistry and Biotechnology, vol. 4, pp. 402-407, 2008.

[8] M. G. Shehata, S. A. El Sohaimy, M. A. El-Sahn, and M. M. Youssef, "Screening of isolated potential probiotic lactic acid bacteria for cholesterol lowering property and bile salt hydrolase activity," Annals of Agricultural Science, vol. 61, no. 1, pp. 65-75, 2016.

[9] M. Boularés, C. Aouadhi, M. Mankai, O. Ben Moussa, I. Essid, and H. Mnasser, "Characterisation, identification and technological properties of psychotrophic lactic acid bacteria originating from Tunisian fresh fish," Journal of Food Safety, vol. 32, pp. 333-344, 2012.

[10] C. Prabhurajeshwar and R. K. Chandrakanth, "Probiotic potential of lactobacilli with antagonistic activity against pathogenic strains: an in vitro validation for the production of inhibitory substances," Biomedical Journal, vol. 40, no. 5, pp. 270-283, 2017.

[11] A. Ljungh and T. Wadström, "Lactic acid bacteria as probiotics," Current Issues in Intestinal Microbiology, vol. 7, pp. 73-89, 2006.

[12] M. T. Aymerich, M. Garriga, J. M. Monfort, I. Nes, and M. Hugas, "Bacteriocin-producing lactobacilli in Spanishstyle fermented sausages: characterization of bacteriocins," Food Microbiology, vol. 17, no. 1, pp. 33-45, 2000.

[13] S. D. Todorov, "Bacteriocin production by Lactobacillus plantarum AMA-K isolated from Amasi, a Zimbabwean fermented milk product and study of the adsorption of bacteriocin AMA-K to Listeria sp," Brazilian Journal of Microbiology, vol. 39, no. 1, pp. 178-187, 2008.

[14] A. Terzić-Vidojević, K. Veljović, M. Tolinački et al., "Diversity of non-starter lactic acid bacteria in autochthonous dairy products from Western Balkan Countries-technological and probiotic properties," Food Research International, vol. 136, Article ID 109494, 2020.

[15] J. Lozo, L. Topisirovic, and M. Kojic, "Natural bacterial isolates as an inexhaustible source of new bacteriocins," Applied Microbiology and Biotechnology, vol. 105, no. 2, pp. 477-492, 2021.

[16] L. Topisirovic, M. Kojic, D. Fira, N. Golic, I. Strahinic, and J. Lozo, "Potential of lactic acid bacteria isolated from specific natural niches in food production and preservation," International Journal of Food Microbiology, vol. 112, no. 3, pp. 230-235, 2006.

[17] G. Vinderola, B. Capellini, F. Villarreal, V. Suárez, A. Quiberoni, and J. Reinheimer, "Usefulness of a set of simple in vitro tests for the screening and identification of probiotic candidate strains for dairy use," Lebensmittel-Wissenschaft und-Technologie- Food Science and Technology, vol. 41, no. 9, pp. 1678-1688, 2008.

[18] FAO/WHO, Probiotics in Food, Health and Nutritional Properties and Guidelines for Evaluation, FAO Food and Nutritional, Rome, Italy, 2006.
[19] O. Hassaïne, H. Zadi-Karam, and N. E. Karam, "Technologically important properties of lactic acid bacteria isolated from raw milk of three breeds of Algerian dromedary (Camelus dromedarius)," Africain Journal of Biotechnology, vol. 6, pp. 1720-1727, 2007.

[20] G. Mulaw, T. Sisay, D. Muleta, and A. Tesfaye, "In vitro evaluation of probiotic properties of lactic acid bacteria isolated from some traditionally fermented Ethiopian food products," International Journal of Microbiology, vol. 2019, Article ID 7179514, 11 pages, 2019.

[21] R. C. Reuben, P. C. Roy, S. L. Sarkar, A. S. M. Rubayet Ul Alam, I. K. Jahid, and I. K. Jahid, "Characterization and evaluation of lactic acid bacteria from indigenous raw milk for potential probiotic properties," Journal of Dairy Science, vol. 103, no. 2, pp. 1223-1237, 2020.

[22] A. Cheriguene, F. Chougrani, and A. Bensoltane, "Identification and characterization of lactic acid bacteria isolated from Algerian goat's milk," Pakistan Journal of Biological Sciences, vol. 9, no. 7, pp. 1242-1249, 2006.

[23] O. B. Moussa, M. Mankaï, K. Setti, M. Boulares, M. Maher, and M. Hassouna, "Characterisation and technological properties of psychotropic lactic acid bacteria strains isolated from Tunisian raw milk," Annals of Microbiology, vol. 58, no. 3, pp. 461-469, 2008.

[24] W. L. G. De Almeida Júnior, Í. S. Ferrari, J. V. De Souza, C. D. A. Da Silva, M. M. Da Costa, and F. S. Dias, "Characterization and evaluation of lactic acid bacteria isolated from goat milk," Food Control, vol. 53, pp. 96-103, 2015.

[25] N. A. Logan, O. Berge, A. H. Bishop et al., "Proposed minimal standards for describing new taxa of aerobic, endosporeforming bacteria," International Journal of Systematic and Evolutionary Microbiology, vol. 59, no. 8, pp. 2114-2121, 2009.

[26] J. P. Guirad, Microbiologie Alimentaire, Dunod, Paris, 1998.

[27] A. B. Melinda, y A. D. Ma, and L. H. Sharon, "Comparison of API $50 \mathrm{CH}$ strips to whole-chromosomal DNA probes for identification of Lactobacillus species," Journal of Clinical Microbiology, vol. 43, pp. 5309-5311, 2005.

[28] C. Aouadhi, A. Maaroufi, and S. Mejri, "Incidence and characterisation of aerobic spore-forming bacteria originating from dairy milk in Tunisia," International Journal of Dairy Technology, vol. 67, no. 1, pp. 95-102, 2014.

[29] A. Klibi, A. Jouini, R. Boubaker El Andolsi et al., "Epidemiology of $\beta$-lactamase-producing staphylococci and Gram negative bacteria as cause of clinical bovine mastitis in Tunisia," BioMed Research International, vol. 2019, Article ID 2165316, 11 pages, 2019.

[30] A. Adetoye, E. Pinloche, B. A. Adeniyi, and F. A. Ayeni, "Characterization and anti-salmonella activities of lactic acid bacteria isolated from cattle faeces," BMC Microbiology, vol. 18, no. 1, p. 96, 2018.

[31] N. Thapa, J. Pal, and J. Tamang, "Phenotypic identification and technological properties of lactic acid bacteria isolated from traditionally processed fish products of the Eastern Himalayas," International Journal of Food Microbiology, vol. 107, no. 1, pp. 33-38, 2006.

[32] M. Kieliszek, K. Pobiega, K. Piwowarek, and A. M. Kot, "Characteristics of the proteolytic enzymes produced by lactic acid bacteria," Molecules, vol. 26, no. 7, p. 1858, 2021.

[33] K. Kateřina, J. Chumchalová, K. Míková, S. Cupáková, and R. L. Karpíšková, "Screening of lactic acid bacteria for antimicrobial properties from mayonnaise-based products and raw materials," European Food Research and Technology, vol. 226, pp. 265-272, 2007. 
[34] T. Somboon, P. Mukkharin, and K. Suwimon, "Characterization and lipolytic activity of lactic acid bacteria isolated from Thai fermented meat," Journal of Applied Pharmaceutical Science, vol. 5, pp. 006-012, 2015.

[35] CA-SFM Communiqué, Comité de l'Antibiogramme de la Société Française de Microbiologie, pp. 1-50, CA-SFM Communiqué, New-Delhi, India, 2005.

[36] S. A. Liasi, T. I. Azmi, M. D. Hassan, M. Shuhaimi, M. Rosfarizan, and A. B. Ariff, "Antimicrobial activity and antibiotic sensitivity of three isolates of lactic acid bacteria from fermented fish product, Budu Malays," Journal of Microbiology, vol. 5, pp. 33-37, 2009.

[37] Y. B. Ngwai, H. N. Nwankwo, and M. P. Adoga, "Multidrug resistant Escherichia coli from human immunodeficiency virus/acquired immunodeficiency syndrome (HIV/AIDS) patients in Keffi, Nigeria," International Research Journal of Microbiology, vol. 2, pp. 122-125, 2011.

[38] G. W. Tannock, A. Tilsala-Timisjarvi, S. Rodtong, J. Ng, K. Munro, and T. Alatossava, "Identification of Lactobacillus isolates from the gastrointestinal tract, silage, and yoghurt by 16S-23S rRNA gene intergenic spacer region sequence comparisons," Applied and Environmental Microbiology, vol. 65, no. 9, pp. 4264-4267, 1999.

[39] N. Jose, C. Bunt, and M. Hussain, "Comparison of microbiological and probiotic characteristics of lactobacilli isolates from dairy food products and animal rumen contents," $M i$ croorganisms, vol. 3, no. 2, pp. 198-212, 2015.

[40] M. Anas, H. J. Eddine, and K. Mebrouk, "Antimicrobial activity of Lactobacillus species isolated from Algerian raw goat's milk against Staphylococcus aureus," World Journal of Dairy \& Food Sciences, vol. 3, pp. 39-49, 2008.

[41] Y. Gao, M. J. Van Belkum, and M. E. Stiles, "The outer membrane of Gram-negative bacteria inhibits antibacterial activity of brochocin-C," Applied and Environmental Microbiology, vol. 65, no. 10, pp. 4329-4333, 1999.

[42] C. M. Bourgeois and J. P. Larpent, Microbiologie Alimentaire: Aliments Fermentés et Fermentations Alimentaires, pp. 432704, Tec \& Doc, Lavoisier, Paris, 1996.

[43] C. A. Campos, Ó. Rodríguez, P. Calo-Mata, M. Prado, and J. Barros-Velázquez, "Preliminary characterization of bacteriocins from Lactococcus lactis, Enterococcus faecium and Enterococcus mundtii strains isolated from turbot (Psetta maxima)," Food Research International, vol. 39, no. 3, pp. 356-364, 2006.

[44] T. Idoui and N. E. Karam, "Lactic acid bacteria from Jijel's butter: isolation, identification and major technological traits," Gracia Aceites, vol. 59, pp. 361-367, 2008.

[45] M. M. A. El-Sawah, A. A. Sherief, and S. M. Bayoumy, "Enzymatic properties of lipase and characteristics production byLactobacillus delbrueckii subsp.bulgaricus," Antonie Van Leeuwenhoek, vol. 67, no. 4, pp. 357-362, 1995.

[46] M. Liu, J. R. Bayjanov, B. Renckens, A. Nauta, and R. J. Siezen, "The proteolytic system of lactic acid bacteria revisited: a genomic comparison," BMC Genomics, vol. 11, no. 1, p. 36, 2010.

[47] F. O. Olufemi, O. M. Chijioke, S. T. Popoola, and O. F. Oluwafemi, "In vitro study of potential probiotic lactic acid Bacteria isolated from the gut of chickens in Abeokuta, Nigeria," Alexandria Journal of Veterinary Science, vol. 58, pp. 73-84, 2018.

[48] M. Z. Hoque, F. Akter, K. M. Hossain, M. S. M. Rhaman, M. M. Billah, and K. M. D. Islam, "Isolation, identification and analysis of probiotic properties of Lactobacillus spp from selective regional yoghurt," World Journal of Dairy \& Food Sciences, vol. 5, pp. 39-46, 2010.

[49] H. Tang, B. Qian, and B. Xia, "Screening of lactic acid bacteria isolated from fermented Cornus officinalis fruits for probiotic potential," Journal of Food Safety, vol. 38, Article ID e12565, 2018.

[50] J. Lukášová and A. Šustáčková, "Enterococci and antibiotic resistance,” ACTA Veterinary BRNO, vol. 72, pp. 315-323, 2003. 